\title{
Master of Theology
}

National Cancer Institute

\section{Source}

National Cancer Institute. Master of Theology. NCI Thesaurus. Code C71377.

An advanced academic degree which is sometimes earned after (or instead of) a Master of Divinity or a Master of Theological Studies. This deg ree can range from a one or two year degree (30-60 credit hours) in general theological studies all the way up to a four year degree (120 credit hours) which offers specialized advanced studies in theological research. 